\title{
PHARMACOECONOMIC ANALYSIS OF THE USE OF RAMIPRIL AND CANDESARTAN IN PATIENTS WITH ARTERIAL HYPERTENSION
}

\author{
(C) A. Marushchak, E. Shorikov
}

\begin{abstract}
Артеріальна гіпертензія (АГ) - найпоширеніше в світі серцево-судинне захворювання і є причиною інвалідизачії населення розвинених краӥн світу. Особливістю фармакотерапї̈ при АГ є довічний прийом лікарських препаратів. Показники економічної оцінки ефективності різних методів лікування сприяють вибору фармакотерапії, яка забезпечить пачієнту найбільшу результативність лікування з урахуванням фінансових можливостей конкретного хворого. Головними завданням антигіпертензивної терапї є досягнення иільового рівня артеріального тиску (АT), захист органів-міменей $і$ позитивний вплив на фактори ризику сериево-судинних ускладнень. Метод «затрати-ефективність» дає можливість співставити витрати при однаковій терапевтичній ефективності, щзо і було метою нашого дослідження.

Матеріали та методи. Досліджено 100 протоколів медичних карток стачіонарних хворих. Виділено 2 групи хворих: перша група для лікування АГ отримувала кандесартан, а друга група - раміприл. До уваги бралися параметри: досягнення цільового АT, а також можливі ускладнення лікарської терапії - гіпотензія, кашель, ангіоневротичний набряк. Для очінки вартості лікування на тлі застосування раміприлу та кандесартану був проведений фармакоекономічний аналіз «затрати-ефективність».
\end{abstract}

Результати дослідження. За допомогою методу „вартість-ефективність” було проведено аналіз раміприлу і кандесартану. Були розраховані мінімальні, середні та максимальні вартості разової, добової та курсової дози і розрахована вартість нормалізації АТ. Отримані нами дані свідчать про меншу вартість лікування раміприлом. Результати аналізу ефективності препаратів продемонстрували, щчо раміприл більш ефективний у досягненні иільового АT, але відсоток побічних ефектів серед яких сериева недостатність і кашель був суттєво вищим. Отримані дані вказують на високу терапевтичну ефективність кандесартану і раміприлу, щчо дозволяє зробити висновки:

Висновки. Найбільи ефективним у досягненні иільового АТ був раміприл по зрівнянню з кандесартаном. Аналіз ефективності дії лікарських препаратів встановив, щяо раміприл має побічні ефекти $і$ викликає кашель і сериеву недостатність, а кандесартан може стати причиною ангіоневротичного набряку $i$ гіпотензії. В ході аналізу прямих затрат на лікування АГ, на основі діючих стандартів надання медичноі допомоги хворим з АГ було встановлено, щьо найменш витратним є лікування раміприлом. Проведений аналіз 《витрати - ефективність», продемонстрував, щзо найбільшою фармакоекономічною перевагою має раміприл

Ключові слова: артеріальна гіпертензія, кандесартан, раміприл, фарамакоекономічний аналіз, гіпотензивні препарати, затрати-ефективність

\section{Introduction}

Arterial hypertension $(\mathrm{AH})$ - the most common cardiovascular disease in the world, which has a significant impact on the structure of disability and mortality of the population of industrialized countries of the world. Hypertension is often accompanied by complications such as myocardial infarction (MI), stroke, chronic heart failure (CHF). The peculiarity of pharmacotherapy in hypertension is usually the lifelong use of medicines. The drugs used today have received a solid evidence base, as well as long stages of clinical and experimental research. Indicators of economic evaluation of the effectiveness of various treatments are criteria that help to select the method of pharmacotherapy, which will provide the patient with the greatest benefit of treatment and the most acceptable quality of life, taking into account the financial capabilities of a particular patient or public health care. The doctor prescribes one or another effective medication based on its cost, which minimizes costs and optimizes the treatment itself [1].
2. Formulation of the problem in a general way, the relevance of the theme and its connection with important scientific and practical issues

In order to assess the quality of medicinal products, it is necessary to apply modern performance criteria. First of all, this is the effectiveness (medical and social efficiency) - the degree of achievement of the desired result of providing medical care taking into account the current level of development of medicine, rationality (scientific validity) - the frequency of application of certain proven useful medical technologies for specific diseases or in specific clinical situations; safe use - introduction without significant risk to patients (benefit from use should exceed the risk of adverse side effects); economic efficiency - rational use of resources, acceptable ratio of costs and results [2].

Today, all recommendations for the treatment of hypertension are considered to be the main goal of antihypertensive therapy, which is to achieve the target blood pressure (BP) level. Another important task is the protec- 
tion of target organs and the positive impact on the risk factors for cardiovascular complications. In this case, successful treatment of arterial hypertension remains a difficult problem, despite the presence of several classes of antihypertensive drugs and efforts to combat the impact of unhealthy lifestyle on blood pressure [3].

Considering the socio-economic status of most Ukrainian citizens, it is necessary to conduct a permanent dynamic pharmaco-economic analysis of minimizing the cost of proper medical care and a corresponding revision of its standards.

\section{Analysis of recent studies and publications in} which a solution of the problem are described and to which the author refers

The rapid development of the pharmaceutical industry has led to the emergence of new drugs, which must meet modern requirements, namely, the effectiveness of exposure should increase with decreasing the cost of the drug. Competition among pharmaceutical companies for the consumer today has caused a number of clinical problems. The method of "minimizing costs" makes it possible to compare costs with the same therapeutic efficacy, but it must be taken into account that the low cost of drugs does not always reduce the cost of treatment in general, as it leads to complications and reduces the effectiveness of medicines [4].

World experience of recent decades has shown that among the recommended modern antihypertensive drugs, angiotensin II receptor blockers (ARB II) occupy a deserved place as first-line drugs along with angiotensin-converting enzyme inhibitors [3].

4. The field of research considering the general problem, which is described in the article

Patients with hypertension receive courses of life-long treatment that require certain economic costs, and often the cost of treatment becomes a reason to stop taking drugs. Therefore, studies that allow the establishment of pharmaco-economic feasibility of the use of drugs for the treatment of hypertension are relevant.

\section{Formulation of goals (tasks) of article}

Therefore, the purpose of our study was to establish a pharmaco-economic assessment of the use of drugs in two groups: candesartan (angiotensin II blockers ARB II) and ramipril (angiotensin converting enzyme inhibitors - ACE inhibitors) that are used to treat hypertension based on cost-effectiveness analyzes [5].

\section{Presentation of the main research material} (methods and objects) with the justification of the results

100 protocols of medical cards of inpatient patients were investigated. Two groups of patients were allocated: the first group for the treatment of hypertension received angiotensin II blockers (ARB II) (candesar$\tan$ ), and the second group, an angiotensin converting enzyme inhibitor, - an ACE inhibitor (ramipril). Attention was drawn to parameters of the blood pressure level, which served as an indicator of the effectiveness of antihypertensive therapy (SAT, DAT). In addition to the criteria of effectiveness (achievement of target BP), possible complications of drug therapy were taken into account - hypotension, cough, angioneurotic edema. Also, the results of biochemical studies (determination of glucose, coagulogram, AST, ALT, creatinine, urea, cholesterol and beta-lipoproteins) were included in the efficiency criterion.

To evaluate the cost of treatment against the background of the use of ramipril and candesartan, a pharmaco-economic cost-effectiveness analysis was conducted to determine the optimal, in terms of pharmaco-economics, an effective drug for the treatment of hypertension.

Research results. Dynamics of indicators of blood pressure in patients is presented in the Table. 1.

Table 1

Dynamics of SAT and DAT levels against the background of treatment with ramipril and candesartan

\begin{tabular}{|c|c|c|c|c|c|}
\hline Drug & $\mathrm{SAT}, \mathrm{mmHg}$ & DAT, $\mathrm{mmHg}$ & Pulse BP, mmHg & $\begin{array}{l}\text { Single dose, } \\
\text { mg }\end{array}$ & $\begin{array}{c}\text { Daily dose, } \\
\text { mg }\end{array}$ \\
\hline & \multicolumn{5}{|c|}{ for 1 day of stay of patients in a hospital } \\
\hline Ramipril & $157 \pm 11 *$ & $98 \pm 8 * *$ & $59 \pm 13.67$ & $6.73 \pm 2.77$ & $7.03 \pm 2.85$ \\
\hline \multirow[t]{2}{*}{ Candesartan } & $167 \pm 24.38 *$ & $95 \pm 13.78$ & $72 \pm 24.09$ & $7.5 \pm 2.67$ & $7.5 \pm 2.67$ \\
\hline & \multicolumn{5}{|c|}{ for 3 day of stay of patients in a hospital } \\
\hline Ramipril & $145 \pm 10 *$ & $87 \pm 9 *$ & $56.67 \pm 7.3$ & $6.73 \pm 2.7$ & $7.03 \pm 2.8$ \\
\hline \multirow[t]{2}{*}{ Candesartan } & $141.66 \pm 11.6^{*}$ & $81.66 \pm 11.6$ & $58 \pm 10.8$ & $7.5 \pm 2.6$ & $7.5 \pm 2.6$ \\
\hline & \multicolumn{5}{|c|}{ for 7 day of stay of patients in a hospital } \\
\hline Ramipril & $131.67 \pm 8.3^{*}$ & $77.92 \pm 8.9$ & $53.34 \pm 10.3$ & $6.73 \pm 2.7$ & $7.03 \pm 2.8$ \\
\hline \multirow[t]{2}{*}{ Candesartan } & $131.66 \pm 11.6^{*}$ & $77.5 \pm 8.8$ & $53.75 \pm 13.4$ & $7.5 \pm 2.6$ & $7.5 \pm 2.6$ \\
\hline & \multicolumn{5}{|c|}{ for 10 day of stay of patients in a hospital } \\
\hline Ramipril & $125.84 \pm 3.93$ & $73.75 \pm 7.1$ & $52.09 \pm 10.53$ & $6.73 \pm 2.7$ & $7.03 \pm 2.8$ \\
\hline \multirow[t]{2}{*}{ Candesartan } & $130 \pm 3.93 *$ & $73.83 \pm 5.1$ & $53.83 \pm 14.67$ & $7.5 \pm 2.67$ & $7.5 \pm 2.67$ \\
\hline & \multicolumn{5}{|c|}{ for 14 day of stay of patients in a hospital } \\
\hline Ramipril & $125 \pm 3.93$ & $73.75 \pm 7$ & $52 \pm 10.53$ & $6.7 \pm 2.7$ & $7.0 \pm 2.8$ \\
\hline Candesartan & $128.84 \pm 8.3 *$ & $73.8 \pm 9.1$ & $53.8 \pm 14.6$ & $7.5 \pm 2.6$ & $7.5 \pm 2.6$ \\
\hline
\end{tabular}


Ramipril normalized blood pressure for the first day the best (23.8\%) (Table 2), and candesartan did it worse $(7.4 \%)$. At the 3rd day, the percentage of normalization of blood pressure accounted for $36.9 \%$ and 35.7 $\%$ for ramipril and candesartan respectively. At 10th day the leader's position is maintained by ramipril $(84.5 \%)$. At day 14 ramipril almost in a hundred percent of cases stabilized BP $(92.8 \%)$.

The results of the analysis of drug efficacy expressed in percent demonstrated that ramipril is more effective in achieving target blood pressure, but the percentage of side effects, including heart failure and cough, was significantly higher (Table 3).
In the 1st group of patients before treatment, glucose levels were elevated $(6.9 \pm 3.27 \mathrm{mmol} / \mathrm{l})$, and after - decreased to the normal limits $(4.5 \mathrm{mmol} / \mathrm{l})$ (Table 4).

The level of glucose in the 2 nd group before treatment was elevated $(6.9 \pm 3.27 \mathrm{mmol} / \mathrm{l})$, and after - decreased to the limits of the norm $(4.7 \mathrm{mmol} / \mathrm{l})$ (Table 4).

In all groups of patients, the level of plasma recalcification time was normal. Hematocrit in the 2nd group was normal, and in the 1 st - slightly increased. The level of the prothrombin index in all groups of patients was within the normal range, and the level of fibrinogen A (fibrinogen plasma) in all groups was elevated (Table 5).

Table 2

Effectiveness of pharmacotherapy with ramipril and candesartan on the percentage of blood pressure normaliza-

\begin{tabular}{|l|c|c|c|c|c|}
\hline Drug & $1^{\text {st }}$ day, $\%$ & $3^{\text {rd }}$ day, $\%$ & $7^{\text {th }}$ day, $\%$ & $10^{\text {th }}$ day, $\%$ & $14^{\text {th }}$ day, $\%$ \\
\hline Ramipril & 23.8 & 36.9 & 73.8 & 84.5 & 92.8 \\
\hline Candesartan & 21.1 & 35.7 & 54.0 & 66.7 & 74.7 \\
\hline
\end{tabular}

Table 3

Results of the analysis of efficiency

\begin{tabular}{|l|c|c|c|c|c|}
\hline Drug & $\begin{array}{c}\text { Achievement of the } \\
\text { target level of BP, } \%\end{array}$ & Hypotension, $\%$ & Cough, $\%$ & $\begin{array}{c}\text { Angioneurotic } \\
\text { edema, } \%\end{array}$ & $\begin{array}{c}\text { Heart failure, } \\
\%\end{array}$ \\
\hline Ramipril & 85 & 1.9 & 9 & - & 9 \\
\hline Candesartan & 64 & 3.7 & 0.4 & 0.2 & 0.8 \\
\hline
\end{tabular}

Table 4

The dynamics of glucose levels in the fasted state and 2 hours after eating

\begin{tabular}{|l|c|c|c|}
\hline \multirow{2}{*}{ Drug } & \multicolumn{2}{|c|}{ Glucose level in the fasted state, mmol / } & $\begin{array}{c}\text { Glucose level 2 hours after eating, } \\
\text { mmol / 1 }\end{array}$ \\
\cline { 2 - 3 } & before treatment & after treatment & $7.33 \pm 1.79^{* *}$ \\
\hline Ramipril & $6.9 \pm 3.27$ & $4.5 \pm 0.06^{*}$ & $7.35 \pm 1.79^{* *}$ \\
\hline Candesartan & $6.9 \pm 3.27$ & $4.7 \pm 0.06^{*}$ & \\
\hline
\end{tabular}

Note: $*-p<0.05 ; * *-p<0.001$

Table 5

The dynamics of the main indicators of the coagulogram

\begin{tabular}{|l|c|c|c|c|}
\hline Drug & $\begin{array}{c}\text { Plasma recalcification } \\
\text { time, sec }\end{array}$ & Hematocrit, $\%$ & Prothrombin index, \% & Fibrinogen A, g/l \\
\hline Ramipril & $97 \pm 13.39^{*}$ & $46.38 \pm 6.16$ & $90.83 \pm 11.06^{*}$ & $4.05 \pm 1.13^{*}$ \\
\hline Candesartan & $95 \pm 13.57^{*}$ & $43.3 \pm 6.95$ & $87.7 \pm 8.07^{*}$ & $3.84 \pm 1.16^{*}$ \\
\hline
\end{tabular}

The level of AST and ALT in the 1st and 2nd group of patients both before and after treatment was within the normal range (Table 5). Creatinine in the 1 st and 2 nd group of patients was normal. The level of urea in all groups was within the normal range (Table 6).The use of ramipril and candesartan did not affect the level of cholesterol, candesartan reduced the level of betalipoproteins in 1.1 times (Table 7).

Table 6

Dynamics of levels of AST and ALT, urea and creatinine

\begin{tabular}{|c|c|c|c|c|c|c|}
\hline \multirow[b]{2}{*}{ Drug } & \multicolumn{2}{|c|}{ AST, mmol / h l } & \multicolumn{2}{|c|}{ ALT, mmol / h 1} & \multirow[b]{2}{*}{$\begin{array}{c}\text { Creatinine, } \\
\text { umol / } 1\end{array}$} & \multirow[b]{2}{*}{ Urea, mmol / 1} \\
\hline & $\begin{array}{c}\text { before treat- } \\
\text { ment }\end{array}$ & $\begin{array}{l}\text { after treat- } \\
\text { ment }\end{array}$ & $\begin{array}{c}\text { before treat- } \\
\text { ment }\end{array}$ & $\begin{array}{l}\text { after treat- } \\
\text { ment }\end{array}$ & & \\
\hline Ramipril & $0.39 \pm 0.15$ & $0.35 \pm 0.21$ & $0.55 \pm 0.28$ & $0.55 \pm 0.21$ & $88.78 \pm 22.46^{*}$ & $6.41 \pm 1.16^{*}$ \\
\hline Candesartan & $0.44 \pm 0.21$ & $0.3 \pm 0.14 *$ & $0.53 \pm 0.12$ & $0.5 \pm 0.2$ & $93.15 \pm 13.17^{*}$ & $6.79 \pm 1.77 *$ \\
\hline
\end{tabular}


Dynamics of cholesterol and beta-lipoprotein levels

\begin{tabular}{|l|c|c|c|c|}
\hline \multirow{2}{*}{ Drug } & \multicolumn{2}{|c|}{ cholesterol, mmol / } & \multicolumn{2}{c|}{ Beta-lipoprotein, units } \\
\cline { 2 - 5 } & before treatment & after treatment & before treatment & after treatment \\
\hline Ramipril & $5.04 \pm 1.46$ & $5.08 \pm 1.32$ & $47.96 \pm 13.54$ & $49.8 \pm 10.02^{*}$ \\
\hline Candesartan & $5.52 \pm 1.71$ & $5 \pm 1.69$ & $55.12 \pm 17.09$ & $50 \pm 14.14^{* *}$ \\
\hline
\end{tabular}

Using the "cost-effectiveness method", an ACE inhibitor (ramipril) and ARB inhibitor (candesartan) were analyzed.

Data on the cost (minimum, average and maximum) of ACE inhibitor (in UAH) were taken at the end of the study (April-May 2017) from the network of pharmacies in Chernivtsi - "Vako", "Harmony", and "Econom-pharmacy" and "Olmamed".

Calculation of the cost of the ACE inhibitor and ARB inhibitor was carried out in stages:

- values of "cost" of normalization of blood pressure: the value of the daily dose is multiplied at the bottom of the normalization of blood pressure;

- "cost" of the course dose: the value of the daily dose is multiplied by the number of bed days. The minimum, average and maximum values of ACE inhibitor and ARB inhibitor were taken into account.

The indicator of the effectiveness of treatment was calculated as the ratio of the number of persons with the target level of blood pressure to the number of persons in whom the blood pressure did not reach the target level.

Thus, the efficiency indicator was for: 1st group $22 / 25=0.88 ; 2$ nd group $-13.18=0.72$.

Calculated expense - intermediate-effect (reflects the cost of normalization of blood pressure) and costefficiency indicator.
Regarding the analysis of the range of prices for the drug "Ramipril," we found the following: the drug at a dose of $5 \mathrm{mg}$ (tab. 30) was the cheapest for the patient at the pharmacy "Econom-pharmacy" (129.50 UAH.).

This dosage at the time of the study was absent in the pharmacy "Harmony" and "Olmamed"; for the drug at a dose of $10 \mathrm{mg}$ (tab. 30) the lowest price was - at the pharmacy "Econom-pharmacy" (250.50 UAH.), and the highest one - in the pharmacy "Olmamed" and "Vako" (265.00 UAH, respectively the same).

For "Candesartan" - $16 \mathrm{mg}$ (tab. 28) the lowest price was - in the pharmacy "Economy-pharmacy" (378.50 UAH.), and the highest one - in the pharmacy "Olmamed" and "Vako" (431.00 UAH, respectively, the same).

At the time of research, ramipril was on average in pharmacies in the city of Chernivtsi with the price within the limits of $158.50 \mathrm{UAH}$ for $5 \mathrm{mg}$ of dosage form N 30 (Table 8). Candesartan -16 mg (tab. 28) - $431.00 \mathrm{UAH}$.

Taking into account the above, we calculated the minimum, average and maximum values of one-time, daily and course dose. Also calculated the cost of normalization of blood pressure. The data is presented in the Table. 9.

Comparison of the values of single-dose for ramipril dose is up to $10.50 \mathrm{UAH}$, and the lowest single dose price for candesartan is $15.39 \mathrm{UAH}$.

Table 8

Averaged prices of ramipril and candesartan of ramipril group per 1 pack.

\begin{tabular}{|l|c|c|c|}
\hline \multirow{2}{*}{ Drug } & \multicolumn{3}{|c|}{ Average packing cost, UAH } \\
\cline { 2 - 4 } & Minimal & Average & Maximal \\
\hline Ramipril mg № 30 & 127.00 & 158.50 & 190.00 \\
\hline Candesartan 4 mg № 28 (Actavis (Slovakia) 16 mg № 28) & 378.00 & 431.00 & 469.00 \\
\hline
\end{tabular}

Table 9

Indicator of the averaged cost of single doses of ramipril and candesartan

\begin{tabular}{|l|c|c|c|}
\hline \multirow{2}{*}{ Drug } & \multicolumn{3}{|c|}{ Cost of single doses, UAH } \\
\cline { 2 - 4 } & \multicolumn{3}{|c|}{ Single dose } \\
\cline { 2 - 4 } & Minimal & Average & Maximal \\
\hline Ramipril & 8.40 & 10.50 & 12.60 \\
\hline Candesartan & 13.50 & 15.39 & 16.75 \\
\hline \multirow{2}{*}{ Drug } & \multicolumn{3}{|c|}{ Cost of course (14 days) dose, UAH } \\
\hline Ramipril & Minimal & Average & Maximal \\
\hline Candesartan & 118.46 & 147.86 & 234.50 \\
\hline \multirow{2}{*}{ Drug } & 189.00 & 215.44 & Maximal \\
\hline Ramipril & Minimal & Average & 352.00 \\
\hline Candesartan & 236.92 & 294.00 & 469.00 \\
\hline \multirow{2}{*}{ Drug } & 333.00 & 430.88 & Maximal \\
\cline { 2 - 4 } & & Cost of course dose (3 months), UAH \\
\hline Ramipril & Minimal & Average & 1056.00 \\
\hline Candesartan & 710.10 & 882.00 & 1407.00 \\
\cline { 2 - 4 }
\end{tabular}


Analysis of patients' expenditure to achieve the target blood pressure level when compared to $5 \mathrm{mg}$ ramipril and $8 \mathrm{mg}$ of candesartan showed that they would have the least amount of money in the use of ramipril than candesartan.

The data we receive show that ramipril is more effective as a hypotensive agent and because of the key importance of the renin-angiotensin system in the pathogenesis of $\mathrm{AH}$, the use of $\mathrm{ARB}$ is pathogenetically grounded, an alternative ACE inhibitor.

For medications from the ARB group, there is still no advantage over ACE inhibitors over the course of $\mathrm{AH}$ and survival prediction. At the same time, the feasibility of their clinical application can be determined by the safety and better portability of ARBs [6, 7].

In CHARM-Alternative studies, 2028 patients were included in which ACE inhibitors could not be administered in view of side effects, the use of candesartan allowed to reduce the probability of a primary endpoint by $23 \%$. Thus, ARBs should be the means of choice in patients with hypertension that do not tolerate ACE inhibitors [8-10].

A double-blind study comparing the efficacy of ARB valsartan, ACE inhibitor captopril found that valsartan did not yield captopril for its effectiveness in hypertension. In monotherapy, hypotension and renal failure were more common in the valsartan group, and cough, rash and taste disturbance - when taking captopril [11-13].
Researchers have found that both effective and ineffective therapy with ACE inhibitors during the month of changes in aggregation capacity of blood is not observed, but treatment within six months can give positive results on the parameters of the biochemical analysis of blood and also cause lower cholesterol, triglycerides and low density lipoprotein $[14,15]$.

\section{Conclusions from the conducted research} and prospects for further development of this field

The obtained data indicate the high therapeutic effectiveness of candesartan and ramipril, which makes it possible to make the following conclusions:

1. The most effective target for BP was ramipril compared with candesartan, although the effects of drugs on lipid spectrum, coagulogram, glucose, and ALT and AST levels were practically the same.

2. An analysis of the efficacy of medicinal products found that ramipril has side effects and causes cough and heart failure, and candesartan can cause angioedema and hypotension.

3. During the analysis of direct costs for treatment of hypertension, based on the existing standards for the provision of medical care to patients with hypertension, it was found that treatment with ramipril is the least costly.

4. The "cost-effectiveness" analysis showed that the largest pharmaco-economic advantage in pharmacotherapy $\mathrm{AH}$ is ramipril, because this therapy requires the least cost to achieve target $\mathrm{BP}$ in comparison with candesartan.

\section{References}

1. Farmakoekonomicheskaya ocenka lekarstvennogo sredstva zokardis (zofenopril) na osnove metodiki «minimizacii zatrat»/ Vdovichenko V. P., Goncharuk V. V., Bronskaya G. M., Korshak T. A., Mahan'kova T. V. // Medicinskie novosti. 2014. P. 56-60.

2. Metodicheskie podhody k formirovaniyu aktual'nyh indikatorov kachestva medicinskoy pomoshchi / Yur'ev A. S., Avksent'eva M. V., Vorob'ev P. A., Gorbunov S. N. // Problemy standartizacii v zdravoohranenii. 2005. Issue 8. P. 14-21.

3. Farmakoekonomicheskiy analiz ispol'zovaniya azilsartana medoksomila v lechenii myagkoy i umerennoy essencial'noy gipertenzii / Nedogoda S. V., Barykina I. N., Salasyuk A. S., Smirnova V. O. // RMZh. 2016. Issue 12. P. 734-738.

4. Yagudina R. I., Serpik V. G., Kulikov A. Yu. Farmakoekonomika dlya organizatorov zdravoohraneniya. Algoritm prinyatiya resheniy na osnove farmakoekonomicheskoy ocenki // Farmakoekonomika: teoriya i praktika. 2014. Vol. 2, Issue 1. P. 5-12.

5. Tolordava G. A., Arinina E. E., Kulikov A. Yu. Farmakoekonomicheskiy analiz lekarstvennogo sredstva fozinopril u bol'nyh s arterial'noy gipertenziey // Farmakoekonomika: teoriya i praktika. 2016. Vol. 4, Issue 1. P. 70-78.

6. Effects of candesartan in patients with chronic heart failure and reduced left-ventricular systolic function intolerant to angiotensin-converting-enzyme inhibitors: the CHARM-Alternative trial / Granger C. B., McMurray J. J., Yusuf S., Held P., Michelson E. L., Olofsson B. et. al. // The Lancet. 2003. Vol. 362, Issue 9386. P. 772-776. doi: http://doi.org/10.1016/s0140-6736(03)14284-5

7. Protective Role of Ramipril and Candesartan against Myocardial Ischemic Reperfusion Injury: A Biochemical and Transmission Electron Microscopical Study / Sheik Uduman M. S. T., Reddy R. B., Punuru P., Chakka G., Karunakaran G. // Advances in Pharmacological Sciences. 2016. Vol. 2016. P. 1-7. doi: http://doi.org/10.1155/2016/4608979

8. Nikolaev N. A. Innovacionnaya antigipertenzivnaya terapiya v svete zavershennyh nauchnyh issledovaniy // Racional'naya Farmakoterapiya v Kardiologii. 2009. Issue 2. P. 89-97.

9. Farmakoekonomicheskaya ocenka lekarstvennogo sredstva Zokardis (ezofenopril) na osnove metodiki minimizacii zatrat / Vdovichenko V. L., Goncharuk V. V., Bronskaya G. M., Korshak T. A., Mahan'kova T. V. // Medicinskie novovsti. 2014. P. 56-60.

10. Korovina E. V. Racional'noe naznachenie antigipertenzivnyh lekarstvennyh sredstv na osnove farmakoepidemiologicheskogo analiza: avtoref. diss. ... kand. med. nauk. Volgograd, 2015. 36 p.

11. Tolparov G. V. Vliyanie blokatorov renin-angiotenzin-al'dosteronovoy sistemy na funkcional'noe sostoyanie pravogo zheludochka pri infarkte miokarda peredney stenki levogo zheludochka // Kubanskiy nauchniy medicinskiy vestnik. 2016. Issue 3 (158). P. 126-129.

12. Martynyuk T. V., Chazova I. E. Preimushchestva azilsartana medoksomila u pacientov s arterial'noy gipertoniey: kak pravil'no osushchestvit' vybor i optimizirovat' antigipertenzivnuyu terapiyu? // Sistemnye gipertenzii. 2017. Vol. 14, Issue 2. P. 30-35.

13. A Meta-Analysis Reporting Effects of Angiotensin-Converting Enzyme Inhibitors and Angiotensin Receptor Blockers in Patients Without Heart Failure / Savarese G., Costanzo P., Cleland J. G. F., Vassallo E., Ruggiero D., Rosano G., Perrone-Filardi P. // Journal of the American College of Cardiology. 2013. Vol. 61, Issue 2. P. 131-142. doi: http://doi.org/10.1016/j.jacc.2012.10.011

14. Angeloni E. Azilsartan medoxomil in the management of hypertension: an evidence-based review of its place in therapy // Core Evidence. 2016. doi: http://doi.org/10.2147/ce.s81776 
15. Cost-effectiveness of the treatment of heart failure with ramipril: a Spanish analysis of the AIRE study / Hart W. M., Rubio-Terres C., Pajuelo F., Juanatey J. R. G. // European Journal of Heart Failure. 2002. Vol. 4, Issue 4. P. 553-558. doi: http://doi.org/10.1016/s1388-9842(02)00087-9

Дата надходження рукопису 22.05.2018

Marushchak Alena, Assistant, Department of Pathological physiology, Bukovinian State Medical University, Theatralna sq., 2, Chernivtsi, Ukraine, 58002

E-mail: marushakaliona@ukr.net

Shorikov Evgeniy, Doctor of Medical Sciences, Associate Professor, Department of Internal Medicine, Clinical Pharmacology and Occupational Diseases, Bukovinian State Medical University, Theatralna sq., 2, Chernivtsi, Ukraine, 58002

E-mail: therapy@bsmu.edu.ua

UDC 615.322:[615.451.16:581.45:582.734.6]:[616-092.19:616.084:616-092.9]

DOI: 10.15587/2519-4852.2018.135748

\begin{abstract}
INFLUENCE OF EXTRACT OF PEACH ORDINARY (PERSICA VULGARIS) LEAVES ON THE STATE OF THYMIC-LYMPHATIC ELEMENT OF THE IMMUNE SYSTEM OF RATS IN CONDITIONS OF CHRONIC IMMOBILIZATION STRESS
\end{abstract}

\author{
(C) O. Mishchenko, G. Zaychenko, Ch. Sharifov, O. Koshova, Yu. Laryanovska, O. Khalieieva
}

\begin{abstract}
Мета - вивчення впливу густого екстракту з листя персика звичайного (ГЕЛП) на стан органів тиміколімфатичної ланки імунної системи щурів за умов хронічного іммобілізаційного стресу.

Матеріали та методи. Модель хронічного іммобілізаційного стресу (ХІС) відтворювали протягом 18 діб шляхом щзоденної чотирьохгодинної іммобілізащії щурів у тісних пеналах. Досліджуваний ГЕЛП, що був отриманий на кафедрі хімії природних сполук НФаУ, з листя персика сорту «Сальве», заготовленого в Таджикистані, вводили внутрішньошлунково в умовноефективній дозі 100 мг/кг. Як препарат порівняння використовували сироп «Імуно-Тон» у дозі 3 мл/кг внутрішньошлунково. Стан тиміколімфатичної ланки імунної системи в умовах ХІС визначали після проведення евтаназії тварин під легким інгаляційним наркозом за результатами дослідження коефіцієнтів маси тимуса і селезінки, а також гістологічного дослідження їх структури на мікропрепаратах, щуо були приготовлені за загальноприйнятою методикою. Для оцінки характеру впливу ГЕЛП на стан органів тиміко-лімфатичної системи щурів в умовах ХІС проводили порівняння з інтактним контролем та контрольною патологією.

Результати дослідження. Встановлено протективний вплив ГЕЛП на стан тиміко-лімфатичної ланки імунної системи в умовах ХІС. У селезінці відмічали збільшення ширини маргінальної зони лімфоїдних фолікулів і муфт та кількості периваскулярних лімфатичних муфт у 1,2 разу $(p<0,05)$ порівняно з контрольною патологією, зниження ознак стресогенної гіпоксії-кількості структур білої пульпи зі спазмом центральних артерій. У тимусі встановлено зниження ступеня змін з третьої-четвертої до першої фази акцидентальної трансформації, щзо підтверджується підвищенням коефіцієнту маси тимуса на 2,7 \% порівняно з контрольною патологією.

Висновки. Доведена здатність ГЕЛП відновлювати порушену в умовах стресу активність органів тиміко-лімфатичної ланки імунної системи. Ймовірно стверджувати, що поліфенольні сполуки ГЕЛП виявляють антиоксидантні властивості, посилюючи активність антиоксидантної системи, а полісахариди - імуностимулювальні, результатом виявлення яких є стреспротекторна дія. За ефективністю ГЕЛП не поступався препарату порівняння «Імуно-Тон»

Ключові слова: густий екстракт, листя персика звичайного, хронічний іммобілізаційний стрес, тимус, селезінка, стреспротекторна дія
\end{abstract}

\section{Introduction}

Stress is a universal physiological response to rather strong effects, which is aimed at mobilizing compensatory mechanisms that can be manifested by the transition from activation of the physiological apparatus to exhaustion as a result of overstrain of the reserve capacity of the organism. Stress can cause factors such as injury, loss of blood, surgical intervention, high and low 